\title{
Correction to: Micropulse trans-scleral diode laser cyclophotocoagulation in refractory glaucoma: an initial experience in Indian eyes
}

\author{
Murali Ariga - Nivean - Pratheeba Devi Nivean • V. G. Madanagopalan • \\ Sujatha Mohan
}

Published online: 6 July 2021

(C) Springer Nature B.V. 2021

\section{Correction to: Int Ophthalmol}

$$
\text { https://doi.org/10.1007/s10792-021-01697-1 }
$$

The article "Micropulse trans-scleral diode laser cyclophotocoagulation in refractory glaucoma: an initial experience in Indian eyes", written by Murali Ariga, Nivean, Pratheeba Devi Nivean, V. G. Madanagopalan, Sujatha Mohan, was originally published online on the publisher's internet portal on 6 February 2021 with Open Access under a Creative Commons Attribution 4.0 International License.
With the author's/authors' decision to cancel Open Access the copyright of the article changed on 3 June 2021 to (C) Springer Nature B.V. 2021 with all rights reserved.

The original article has been corrected.

Publisher's Note Springer Nature remains neutral with regard to jurisdictional claims in published maps and institutional affiliations.
The original article can be found online at https:// doi.org/10.1007/s10792-021-01697-1.

M. Ariga

Swamy Eye Hospital, Chennai, India

Nivean · P. D. Nivean $(\varangle)$

MN Eye Hospital, Chennai, India

e-mail: devi.nivean@gmail.com

V. G. Madanagopalan

JB Eye Care and Retina Centre, Vitreoretinal Services,

Salem, India

S. Mohan

Rajan Eye Care, Chennai, India 